DOI https://doi.org/10.18551/rjoas.2017-01.21

\title{
THE EFFECTS OF TRANSFORMATIONAL LEADERSHIP AND PERSONALITY ON EMPLOYEE PERFORMANCE IN NISSAN MALANG MEDIATED BY ORGANIZATIONAL COMMITMENT
}

\author{
Sudiantha David*, Armanu, Troena Eka Afnan \\ Faculty of Economics and Business, University of Brawijaya, Indonesia \\ *E-mail: david.sudiantha@gmail.com
}

\begin{abstract}
This research aims to examine and analyze the effect of transformational leadership, personality, and organizational commitment on employee performance in Nissan Malang. This explanatory study uses SEM-PLS method to analyze and test the propose hypotheses and online sobel test to examine the mediation. The result indicate that transformational leadership has no significant effects on organizational commitment and employee performance, and personality and organizational commitment has signifikan effects on employee performance. In addition, personality shows a significant effect on organizational commitment. Further, the relationship between transformational leadership and employee performance are mediated by personality and not by organizational commitment. One of the proposed reasons for the insignificancy is two factors of transformational leadership, inspirational motivation and individualized consideration not implemented optimally in Nissan Malang. This affect to the low of organizational commitment in Nissan Malang.
\end{abstract}

\section{KEY WORDS}

Transformational leadership, personality, organizational commitment, performance.

Employee involvement (SDM) has a significant role in maintaining and increasing organizational performance (Markos, 2010). Nissan Motor Indonesia (NMI), as one of a great automotive company that make a great effort to increase Indonesian market share from 5,4 $\%$ in 2015 to more than $6 \%$ in 2016 , has to take care and develop the involvement of the employees that shown by their performance. This performance refers to how employee achieves the goal and the target determined by organization (Rothman and Coetzer, 2003).

According to Robinson (2004) the employee involvement should be considered in business context and in working environment to increase the organizational performance. It has a strong relationship with organizational performance where it can decrease employee turnover and increase employee commitment, productivity, profitability, growth and customer satisfaction. (Markos, 2010). Therefore, human resource is organizational key element where organizational success and fail depend on performance of the employees. Moreover, company should develop employee's skill through training in order to reach organizational goal. So, there is a strong relationship between employee development and employee performance. According to Elena (2000) open minded employees indicate that they will never satisfy to what they had done before. They will try to make more development in the future and, finally, will show a high performance.

Through the development of employee skill, company will be able to have competitive employee to compete with others in global competition. Human resource management is how company conducts training process, evaluates and cares with wealth, work security and compensation of employee (Dessler, 2012). Therefore, company success depends on the role of human resource management and relevant work management. Both human resource management and work management are related each other. Work management deals with the process of identification, measurement, management and development of employee performance in organization. Further, the contribution of employee performance becomes a determinant of organizational performance. Performance evaluation is related with the present and the past of the fulfillment of organizational performance standard. This can be 
viewed by high and low employee performance in finishing the job and responsibilities given by company.

One of the key factors that affects to employee performance is leadership. According to Slack (1997) leadership has an important role in developing employee, make a big changes to the whole of organizational elements, and encourage members to achieve organizational goal. Effective leadership is determined by leader's trait and behavior that shown in the leadership styles. An appropriate leadership style can encourage employee to work in maximal and optimal way. One of them is transformational leadership style (Bass and Avolio, 1999).

Another factor that affects performance is personality (Barrick dan Mount, 1991). Personality is one of the predictors of employee performance. The emergence of the big five theory (after 1990) became a gateway of measurement on the effects of the relationship between personality and performance. In the context of employee performance, personality is used to recruit, select, and develop employee's carrier to look for potential employee with high performance. (Klang, 2012). It is the way how to make employee's attitude and behavior related with adaptation process in the working environment (Robbins, 2013).

Performance can be affected also by organizational commitment (Meyer, 2002). Organizational commitment refers to employee's attitude, behavior, and characters such as loyalty, responsibility, and sense of belonging in organization and its objective (Rainayee, 2013). In addition, organizational commitment can influence employee in absence level, relevant job, and rolling job. It is also related with work satisfaction, work involvement, and higher motivation (Mowday et al., 1982). Therefore, higher commitment, higher performance will be produced by the employees.

Organizational commitment becomes a mediator among transformational leadership, personality, and employee performance. It is assumed that transformational leadership and personality as a predictor of organizational commitment. This indicates that through transformational leadership encourages employee's organizational commitment concerning decision making process, inspiring loyalty, accepting and appreciating different needs from employees to develop their potential skill (Bass dan Avolio, 1999).

\section{LITERATURE REVIEW}

Transformational Leadership. Transformational leadership is one of the various modern leadership styles. It includes charismatic element. Bass argued that charismatic leadership is one part of transformational leadership (Luthans, 2010). Transformational leadership is based on leader's values changes, believe and need to followers. Transformational leadership is an perspective that explores how to leader changes team or organization by creating, communicating, and making organizational statement vision model or work unit and inspiring employees to reach its objective (Robbins, 2013). According to Bass, characteristics of Transformational leadership as follows (Robbins, 2013): (1). Idealized Influence: provides vision and sense of mission, instills pride, gains respect and trust. (2). Inspirational Motivation: Communicates high expectations, uses symbols to focus efforts, expresses important proposes in simple ways. (3). Intellectual Stimulation: promotes intelligent, rationality, and careful problem solving. (3). Individualized Consideration: gives personal attention, treats each employee individually, coaches, advises.

This leadership style is a description of leader needed in modern organization where the challenge for business competition raises and global based or limitless. Therefore, visionary leader by challenge worker to give more their performance beyond the expectation to organization is needed. Moreover, ideal leader is a leader who can combine both transformational and transactional leadership model will be able to help organization reaching organizational performance effectively. Transformational is leadership that can encourage followers to show their performance beyond their expectation and to trigger the emergence of employee's organizational commitment in decision making process, inspiring loyalty, accepting and appreciating different need among followers to develop their potential, and rewarding performance. 
Leadership is a part of successful support in organization in which leader manages and affects follower to act and behave like what leader expected in order to support gaining organizational aims. One of the indicators of organizational success can be measured by employee performance and it will be optimized by the role of transformational leadership. Transformational leadership changes team or organization by creating, communicating, and making organizational statement vision model or work unit and inspiring employees to reach its objective. Through this transformational leadership leader can motivate and inspire employees to provide their best ability for company, work creatively and innovatively, and becoming ambitious worker to support to organizational objectives.

The Big Five Theory. John Bearden has proven how to make and rethink ways in managing people. For the last few years, researches indicates that the basic five dimensions became significant characteristics for human personality. Those primary five personality model are as follow (Robbins, 2013): (1). Extraversion. The extraversion dimension captures our comfort level with relationships. Extraverts tend to be gregarious, assertive, and sociable. Introverts tend to be reserved, timid, and quiet. (2). Agreeableness. The agreeableness dimension refers to an individual's propensity to defer to others. Highly agreeable people are cooperative, warm, and trusting. People who score low on agreeableness are cold, disagreeable, and antagonistic. (3). Conscientiousness. The conscientiousness dimension is a measure of reliability. A highly conscientious person is responsible, organized, dependable, and persistent. Those who score low on this dimension are easily distracted, disorganized, and unreliable. (4). Emotional Stability. The emotional stability dimension - often labeled by its converse, neuroticism - taps a person's ability to withstand stress. People with positive emotional stability tend to be calm, self-confident, and secure. Those with high negative scores tend to be nervous, anxious, depressed, and insecure. (5). Openness to Experience. The openness to experience dimension addresses range of interests and fascination with novelty. Extremely open people are creative, curious, and artistically sensitive. Those at the other end of the category are conventional and find comfort in the familiar.

The big Five Theory provides ideal personality profile of employee in their carrier. This leads to the concept that different characteristic is needed in current different job. In addition, the relationship between personality and job will influence the employee performance. Personality is the way people act and behave with others. In the work context, there are various dimensions in principal personality that required by employee to support their optimal performance for company.

Organizational Commitment. Previous studies about organizational commitment became primary research since 1990, a large numbers of studies have been conducted (Meyer et al, 2002). Organizational commitment is multidimensional concept that consist of various things related with different consequences in the whole dimensions. Organizational commitment reflects a level where employee believes and perceives organizational objectives and commits to maintain membership in organization (Sopiah, 2008:155). There are three commitment components model developed by Meyer dan Allen (Meyer et al., 2002): (1). Affective commitment: it means emotional relationship and employee involvement in organization. In other word, this kind of commitment associated with strong emotional attachment to the organization. This is caused by various factors such as personal characteristics and work experienced (2). Normative commitment: it refers to individual's commitment and remains with an organization because of feelings of obligation. Various factors affect this such as personal characteristics, social experienced and organizational investment. (3). Continuance commitment: it refers to the gains and losses that may occur when employee stays or leaves an organization. It consists of Individual characteristics, alternative choices, and investment.

. Organizational commitment is an attitude and behavior that leads to the level of loyalty, responsibility, and sense of belonging toward organization and its goal. This states that the relationship between employee's commitment and contribution to high performance in which this commitment leads to believe and accept the organizational objectives and maintain membership in organization. 
Organizational commitment indicates extend and relative relational forces between individual and organization. The characteristics are trust and acceptance for organizational values, intention to contribute maximum effort and involvement in organization. Organizational member who has high loyalty to organization will possess a strong intention to help organization achieving goals. Higher understanding and involvement toward organization, higher commitment will be. Therefore, organizational commitment has an important role to support organization. In addition, employee's commitment is one of the keys of the growth of company in the future.

Performance has extent understanding, it is not only related with finishing the job, but also correlated to how to performance process conducted. According to Armstrong and Baron (1995) (in Wibowo, 2007) performance derives from work result that associated with strategic organizational goals, and customer satisfaction. Moreover, performance is a part of what should be done and how to do it. Performance is implementation of planning which includes human resource as an executant. Therefore, employee's reward should be considered by organization to make their attitude and behavior supporting organization target (Wibowo, 2007).

In the process of organizational performance, monitoring, evaluating, and reviewing to human resource performance must be considered (Wibowo, 2007). Those are related each other. By monitoring, organization can measure and evaluate performance continuously to get performance progress. While, by evaluating, organization can review to look for problems in performance process. Finally, it is possible to organization to correct and revise the planning and performance implementation.

Bernandin and Russel (1993) noted that there are several dimensions to evaluate employee performance (Azizah, 2015) such as: (1). Quality. It refers to the process or result of program implementation that close to expected or targeted goal. (2). Quantity. It refers to the total production such as profit, number of production units, and total program cycle finished. (3). Timeliness. It relates to the amount of hours or time to use and finish a job that should be faster than the time standard given. (4). Cost Effectiveness. It associates with optimal use of company resources such as technology, financial, and human resource to produce maximum profit and minimize losses of resources. (5). Need for Supervision. It correlates to how far employee provides optimal ability to finish job without supervision. (6). Interpersonal Impact. It refers to how far employee can make conducive condition, comfort at work, has a pride and reputation, and cooperate with other worker.

Employee performance is one of the measurements for organizational performance progress. The development and company progress is determined by human resource performance. Thus, the measurements of employee performance has significant role in organizational evaluation process. The measurement that has an objective to evaluate the optimal work result of employee has several indicators such as quality, quantity, timeliness, cost effectiveness, need for supervision, dan interpersonal impact.

\section{CONCEPTUAL FRAMEWORK}

In the context of business competition rises for a few recent years, Nissan as an automotive company considers human resource as an important element. High contribution from human resource leads to high performance of the company. This makes organizational goal closer to reach. Therefore, there are various efforts to ensure the maximum and optimum employee performance. Company should make sure the organization can increase employee performance. One of the ways is by ensuring well-leadership style implemented in the organization. Company leader has to be able to understand deeply which leadership styles is fit as well as relevant to company's culture. This is assumed by many researchers for long dynamic conversation that transformational leadership is one of the ideal model of leadership style for modern organization. One of the reasons is this style provides trigger, inspiration, and motivation to employees to act, behave and contribute their potential ability beyond their own expectation for the organization. This can inspire followers to be creative 
and innovative at work, accept and implement organizational goal, and motivate employees to have more intention to help organization achieving its aims in the future.

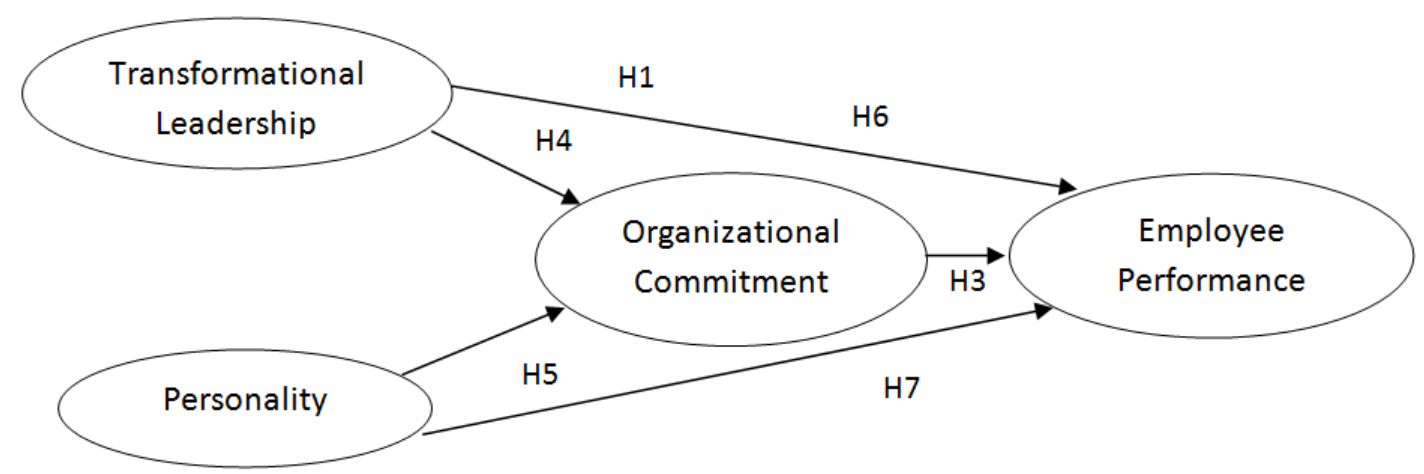

H1: There is a significant effect between transformational leadership and employee performance;

H2: There is a significant effect between personality and employee performance;

H3: There is a significant effect between organizational commitment and employee performance;

H4: There is a significant effect between transformational leadership and organizational commitment;

H5: There is a significant effect between personality and organizational commitment;

H6: There is a significant effect between transformational leadership and employee performance mediated by organizational commitment; H7: There is a significant effect between personality and employee performance mediated by organizational commitment.

Figure 1 - Conceptual Framework

Performance can be also influenced by personality. It has an important role to produce high performance. Appropriate personal characteristics and job leads to work satisfaction that shows in the high employee performance. Thus, employees have well understanding related with their role and responsibility and they can develop their selves. In addition, organizational commitment becomes another factor that affects performance as well as personality. By high commitment to organization, employees have relative force involvement in the growth of organization in the future. Therefore, the conceptual framework of this study is shown as Figure 1.

\section{METHODS OF RESEARCH}

This explanatory study uses quantitative approach. This research was conducted in Nissan Malang by using 51 employees as samples. While Questioner and interview is used as collecting data technique, likert scale is used to measure variables. In addition, to test and analyze the propose hypotheses, this study uses SEM-PLS and to examine the mediation uses online sobel test.

\section{RESULTS OF RESEARCH}

Based on PLS analysis, this study examines the effects of transformational leadership, personality, and organizational commitment on employee performance, and the results are shown in the Table 1.

Table 1 - Result of Hypotheses test

Path Coefficients (Mean, STDEV, T-Values)

\begin{tabular}{|c|c|c|c|c|c|}
\hline & Original Sample (0) & Sample Mean (M) & Standard Deviation (STDEV) & Standard Error (STERR) & T Statistics (|0/STERR|) \\
\hline $\mathrm{X} 1 \rightarrow \mathrm{Y}$ & 0,154099 & 0,158053 & 0,087099 & 0,087099 & 1,769232 \\
\hline $\mathrm{X} 1 \rightarrow \mathrm{Z}$ & 0,004222 & 0,008427 & 0,111745 & 0,111745 & 0,037785 \\
\hline $\mathrm{X} 2 \rightarrow \mathrm{Y}$ & 0,495000 & 0,503175 & 0,086631 & 0,086631 & 5,713900 \\
\hline $\mathrm{X} 2 \rightarrow \mathrm{Z}$ & 0,578743 & 0,576004 & 0,073371 & 0,073371 & 7,887926 \\
\hline $\mathrm{Z} \rightarrow \mathrm{Y}$ & 0,337134 & 0,329102 & 0,072143 & 0,072143 & 4,673134 \\
\hline
\end{tabular}


Table 1 indicates that transformational leadership has no significant effect on employee performance. It has t-statistic 1.769 lower than t-tabel (1.96). Thus, the hypothesis 1 is rejected. It also reports that personality has high T-statistic 5.713 compared to t-table (1.96). This indicates that personality has significant effect on employee performance. Thus, the hypothesis 2 is accepted. In addition, the value of T-statistic for organizational commitment and employee performance variable is higher compare to its T-table, $4.673>1,960$. It means that organizational performance affects employee performance. Thus, the hypothesis 3 is accepted.

It is also stated that 0.037 is T-statistics for the relationship between transformational leadership and organizational commitment. This value lower than significant standard, Ttable 1,960. It indicates that there is no significant effect between transformational leadership and organizational commitment. Thus, the hypothesis 4 is rejected.

Table 1 shows that personality has significant effect on organizational commitment. It can be seen from the comparison value of T-statistics and T-table from personality and organizational commitment variable, $7.887>1.96$. Thus, the hypothesis 5 is accepted. Moreover, for hypotheses 6 and 7 found that T-statistics for transformational leadership variable and employee performance mediated by organizational commitment is 0.037 . In addition, looking at the value of $p$-value $=0.969$. This value not qualified as a significant standard 0.05. It should be lower than a significant value. Thus, the hypothesis 6 is rejected. While organizational commitment mediated the relationship between transformational leadership and employee performance is significant and positive. This is proven by the value of T-statistics higher than T-table $(4.020>1.960)$ and P-value 0.000 lower than 0,05 . Thus, the hypothesis 7 is accepted.

\section{DISCUSSION OF RESULTS}

Based on data analysis found that transformational leadership has no significant effects on employee performance. Of four indicators of transformational leadership (idealized influence, inspirational motivation, intelectual stimulation and, individualized consideration), inspirational motivation and individualized consideration have lower value than other indicators. This indicates leaders in Nissan Malang have not enough ability to motivate and transfer hope and goal to employees. The simple and understandable ways is needed to use by leaders to get more valuable contribution and high performance from the employees. In addition, leaders require massif attachment with and create intent communication to, give advises and take care into the employees.

This study also proves that personality can affect employee performance by strong relationship between both variables in which the correlation values indicate positive and linier both of them. Personality is one of the predictor that influence employees performance that related to how to select, recruit, and develop their carrier in create their high performance (Klang, 2012). Robbin (2013) noted that personality is how employee's attitude and behavior in adapted work environment, acting with other worker and adjusting with their job. This statement shows that employee characteristics should link with what company needed. In the form of job replacement, there are several major personality dimensions that should be considered by company to choose for the employees to support the optimum organizational performance. Those include The Big five theory that consist of extraversion, agreeableness, conscientiousness, emotional stability, and openness to experience.

For the hypothesis 3, the finding presents that there is a significant effect between organizational commitment and employee performance. This result show that organizational commitment related with employee's attitude and behavior that includes loyalty, turnover, responsibility, and sense of belonging to organization and its objectives (Rainayee, 2013). Moreover, organizational commitment can make changes to employee in the forms of absenteeism, tardiness, job performance, citizenship behavior, and job satisfaction (Mowday et al., 1982). Therefore, how far the involvement of the employee in the organization, it will be in line with performance contributed. In other words, organizational commitment is one of the supporting factor that can make company close to its goal. 
Related with the relationship between transformational leadership and organizational commitment, this research found that there is a negative correlation both of them. One of the reasons is less of implementations of transformational leadership characteristics, especially for inspirational motivation and individualized consideration that leads to less of employee commitment to organization. Another factor is turnover intention caused the decrease of company performance in front of competitor companies that consider employee to have more possibility to choose.

Based on data analysis on hypothesis 5 , personality is proven has a significant effects on employee performance. This indicates that personality is one of the predictors of organizational commitment through appropriate personal characteristics and job that emerges emotional relationship and loyalty in organization. The employees will stay longer because they feel comfort with their position and condition in organization. Thus, finally, this can increase their performance as an expected. There are three components of organizational commitment; affective organizational commitment, continuance organizational commitment, and normative organizational commitment (Meyer, 2002). The employees with high organizational commitment can contribute optimally, and responsible to their jobs and tasks given.

The result of this study rejected hypothesis 6 . It is not only there is no relationship between transformational leadership and employee performance directly, but also the relationship between both of them indirectly that mediated by organizational commitment. As noted, there are three correlation in mediation process which all of them must be positive to state that one variable has mediation function; (a) the direct correlation between transformational leadership and employee performance, (b) the correlation between organizational commitment and employee performance, and (c) the indirect correlation between transformational leadership and employee performance that mediated by organizational commitment.

A negative consequence of the indirect relationship between transformational leadership and employee performance mediated by organizational commitment are caused by maintaining membership in organization. But in the same time, the employees consider turnover intention to leave organization for their future carrier. This may be also caused by company high pressure that do not proportional with the decrease of market share and social purchasing power.

In the result of direct effect of personality on employee performance, this study reports a positive and significant influence between both of them. This finding links with hypothesis 7 that indirectly has positive and significant effect both of them mediated by organizational commitment. This indicates that personality is one of the predictors of organizational commitment and encourage the emergence of organizational commitment through the appropriate personal characteristics and job. Thus, this relationship provides emotional ties and loyalty to organization that will make employees have no turnover intention and maintain membership in organization. Finally, by this condition, they will contribute optimal performance to organization.

\section{CONCLUSION}

This study was conducted to examine and analyze the effect of transformational leadership, personality, and organizational commitment on employee performance in Nissan Malang. It can be concluded, as follow:

1. There is no direct significant effect of transformational leadership on employee performance. This points that Nissan Malang leaders do not implement transformational leadership characteristics especially inspirational motivation and individualized consideration.

2. Personality has direct significant effect on employee performance. Extraversion, agreeableness, conscientiousness, emotional stability, openness to experience are personality characteristics that have important role to support employees 
performance in which a agreeableness and openness to experience have a dominant contribution affected on employee performance.

3. Organizational commitment has direct significant effects on employee performance. Continuance commitment represents a majority of Nissan employees commitment where they have emotional ties, feeling and involvement to organization because the appropriate personal characteristics.

4. Transformational leadership has no direct significant effects on organizational commitment. This indicates that leader of Nissan Malang do not implement transformational leader yet, especially in the form of inspirational motivation and individualized consideration. This means also that leader is less in inspiring, motivating, internalizing hope, vision and mission of the organization and taking into account on employees.

5. Personality has direct significant effects on organizational commitment. Higher suitability of work with personal characteristics, higher organizational commitment will be. The dominant effects among personality characteristics is contributed by agreeableness and openness to experience.

6. Organizational commitment do not mediate the effects of transformational on employee performance. It means that organizational commitment cannot strengthen the relationship between transformational leadership and employee performance.

7. Organizational commitment mediates the effects of personality on employee performance. This indicates that the effects of personality can be strengthened by organizational commitment. Thus, personality is an important factor that leads to high organizational commitment and employee performance.

\section{RECOMMENDATIONS}

Like Nissan way philosophy "the power comes from the inside", it states that company success depends on supporting components that comes from the inside of organization that is human resource. Thus, human resources have an important role to support organization reaching and achieving its goal, and it will be easy by implementing transformational leadership style, having suitability personal characteristics, and maintaining high organizational commitment. Therefore, Nissan Malang should try to develop their human resource ability and skill to get high employee performance, especially by evaluating and implementing transformational leadership style.

The important of personal suitability with work environment and organizational needs has a significant role in increasing employee performance. Therefore, Nissan Malang should provide more attention in recruitment, selection, and development of the employee.

Nissan Malang should develop the employees that have more organizational commitment to organization to optimize their performance and carrier in the future. Thus, leader must take into account to the whole stakeholder of the organization to help each other, in developing relevant and valuable policies, interacting with working environment, and understanding the employee's personality.

\section{REFERENCES}

1. Avolio, B.J. \& Bass, B.M. (1999). Re-examining the components of transformational and transactional leadership using the Multifactor Leadership Questionnaire. Journal of Occupational \& Organisational Psychology, 72 (4), 441-462.

2. Azizah, F. N. (2015). Pengaruh Kepemimpinan Situasional dan Budaya Organisasi terhadap Motivasi Kerja dan Kinerja Karyawan (Studi pada Koperasi Agro Niaga (KAN) Jabung Malang). Tesis. Program Pasca Sarjana Fakultas Ekonomi dan Bisnis Universitas Brawijaya.

3. Barrick, Murray and Michael Mount (1991). The big five personality dimensions and job performance: A meta-analysis. Journal Personnel Psychology, Vol. 44, Issues 1, pp 1-26. 
4. Robbins, Stepehen dan Timothy Judge. (2013). Organizational Behaviour. Person Education International Corporate. United State of America.

5. Klang, Andreas. (2012). The relationship between pesonality and job performance in Sales: A. Replication of past research and an extension to a Swedish Context. Thesis. Stockholm University.

6. Luthans, Fred. (2010). Organizational Behavior An Evidence Based Approach Tweflth Edition. McGraw-Hill Irwin. United State of America.

7. Markos, Solomon dan Sandhya Sridevi. (2010). Employee Engagement: The Key to Improving Performance. International Journal of Business and Management, Vol. 5, No. 12, pp. 89-96.

8. Meyer, Jhon, David J. Standley, Lynne Herscovitch, Laryssa Topolnytsky. (2002). Affective, Continuence, and Normative Commitment the Organization: A meta-analysis of Antecedents, Correlates and Consequences. Journal of Vocational Behavior 61, pp. 2052.

9. Sopiah. (2008). Perilaku Organisasi. ANDI Yogyakarta. Yogyakarta

10. Wibowo. (2007). Manajemen Kinerja. PT. Rajagrafindo Persada. Jakarta. 